\title{
Hemşirelik Öğrencilerinin Bireysel Girişimcilik Algıları ve Yaşam Boyu Öğrenme Eğilimleri Arasındaki ílişkinin Belirlenmesi $\infty$
}

\author{
Fatma KILAVUZ ${ }^{1}$, Arzu KARABAĞ AYDIN ${ }^{2}$
}

\section{ÖZ}

Amaç: Çalışma hemşirelik öğrencilerinin bireysel girişimcilik algıları ve yaşam boyu öğrenme eğilimleri arasındaki ilişkinin belirlenmesi amacıyla yapılmıştır.

Gereç ve Yöntem: Tanımlayıcı olarak yapılan çalışmanın uygulaması 1-7 Mart 2018 tarihleri arasında Türkiye'nin Kuzeydoğu Anadolu Bölgesinde bulunan bir üniversitenin sağlık bilimleri fakültesi hemşirelik bölümünde öğrenim gören 523 (\%71.2) gönüllü öğrenci ile gerçekleştirilmiştir. Veri toplama aracı olarak; Tanıtıcı Bilgiler Formu, Bireysel Girişimcilik Algı Ölçeği ve Yaşam Boyu Öğrenme Eğilimleri Ölçeği kullanılmıştır. Verilerin değerlendirilmesinde öncelikle ölçek toplam puanının ve ölçek alt boyut toplam puanlarının tanımlayıcı istatistikleri yapılmıştır. Verilerin analizinde ise Mann-Whitney U, Kruskal Wallis-H ve Spearman Korelasyon Testleri kullanılmıştır.

Bulgular: Araştırmaya katılan öğrencilerin \%57.7'sinin kadın ve yaş ortalamasının 20.99 \pm 2.05 olduğu saptanmıştır. Hemşirelik öğrencilerinin Bireysel Girişimcilik Algı Ölçeği toplam puan ortalaması $119.98 \pm 15.30$ olarak, Yaşam Boyu Öğrenme Eğilimleri Ölçeği toplam puan ortalaması ise $80.80 \pm 20.62$ olarak bulunmuştur. Ailenin aylık gelir durumu ve düzenli kitap okuma alışkanlığı değişkenlerinin hem Bireysel Girişimcilik Algı Ölçeği hem de Yaşam Boyu Öğrenme Eğilimleri Ölçeği puanlarını anlamlı düzeyde etkilediği saptanmıştır $(p<0.05)$. Bireysel Girişimcilik Algısı Ölçeği ile Yaşam Boyu Öğrenme Eğilimleri Ölçeği arasında negatif yönlü zayıf anlamlı bir ilişki saptanmıştır ( $p<0.001, r=-0.164)$.

Sonuç: Çalışmada bireysel girişimcilik algıları yüksek olan hemşirelik öğrencilerinin yaşam boyu öğrenme eğilimlerinin daha düşük olduğu sonucuna ulaşılmıştır.

Anahtar kelimeler: Devamlı hemşirelik eğitimi, girişimcilik, hemşirelik öğrencileri, öğrenme

\begin{abstract}
Determining the Correlation between Nursing Students' Individual Entrepreneurship Perceptions and Lifelong Learning Trends

Aim: The aim of this study was to determine the correlation between nursing students' individual entrepreneurship perceptions and lifelong learning trends.

Material and Methods: This descriptive study was conducted between 1 and 7 March 2018. The study sample consisted of 523 (71.2\%) volunteer students studying at a nursing department of the faculty of health sciences of a university in the Northeastern Region of Anatolia of Turkey. Data were collected using a Descriptive Characteristics Form, the Individual Entrepreneurship Perception Scale and Lifelong Learning Trends Scale. In the evaluation of the data, firstly, descriptive statistics of the scale total score and subscale total scores were made. In the analysis, Mann-Whitney U, Kruskal Wallis-H and Spearman Correlation tests were used.

Results: Of participants, $57.7 \%$ were women. The mean age of participants was $20.99 \pm 2.05$ years. Participants had a mean Individual Entrepreneurship Perception Scale and Lifelong Learning Trends Scale score of $119.98 \pm 15.30$ and $80.80 \pm 20.62$, respectively. The two variables "family income" and "habit of reading regularly" had a significant effect on both scales scores $(p<0.05)$. Individual Entrepreneurship Perception Scale was weakly and negatively correlated with Lifelong Learning Trends Scale $(p<0.001, r=-0.164)$. Conclusion: In the study, it was concluded that nursing students with higher perception of individual entrepreneurship had lower lifelong learning tendencies.

Keywords: Continuing nursing education, entrepreneurship, learning, nursing students
\end{abstract}

${ }^{1}$ Bilim Uzmanı Hemşire, Öğretmen Necla Kızılbağ Huzurevi Yaşlı Bakım ve Rehabilitasyon Merkezi, Ankara, Türkiye, E-mail: fatmakocaoglu_06@hotmail.com, Tel: 0553 267 1997, ORCID: 0000-0003-2351-1455

${ }^{2}$ Dr, Kafkas Üniversitesi, Sağlık Bilimleri Fakültesi, Hemşirelik Bölümü, Kars, Türkiye, E-mail: akarabag.aydin@gmail.com, Tel: 0555 553 1543, ORCiD: 0000-0002-00024091

Geliş Tarihi: 17 Şubat 2020, Kabul Tarihi: 1 Eylül 2020

* Bu çalışma, Dr. Arzu Karabağ Aydın danışmanlığında Fatma Kılavuz'un yüksek lisans tezinden hazırlanmıştır.

Atıf/Citation: Kılavuz F. Karabağ Aydın A. Hemşirelik Öğrencilerinin Bireysel Girişimcilik Algıları ve Yaşam Boyu Öğrenme Eğilimleri Arasındaki İlişkin in Belirlenmesi. Hacettepe Üniversitesi Hemşirelik Fakültesi Dergisi 2020; 7(3):240-248. DOI: 10.31125/hunhemsire.834097 


\section{GíRiş}

Girişimcilik becerilerinin geliştirilmesi hemşirelik eğitiminin amaçlarından biri olarak görülmektedir. Hemşirelikte girişimcilik, hasta bakımında yaratıcı ve yenilikçi yöntemlerin yanı sıra hemşirelerin işle ilgili belirsizlik ve karmaşıklıkla başa çıkabilme becerisini de geliştirmektedir ${ }^{1-3}$. Yaşlanan nüfusun artışına paralel olarak kronik hastalıklarda da görülen artış, artan maliyetler, hemşirelik bakımında değişikliklere ve yeni yaklaşımlara ihtiyaç olduğunu göstermektedir. Bu nedenlerle, bireyin sağlığını sürdürmek ve geliştirmek amacıyla planlanması gereken bakım uygulamaları, girişimci hemşirelere duyulan ihtiyacı ortaya çıkarmaktadır ${ }^{4,5}$. Girişimci olmak hemşirelerin kendilerini keşfetmesini gerektirmektedir ${ }^{6}$. Uluslararası Hemşireler Birliği (International Council of Nurses-ICN) (2004) hemşire girişimcilerin; güçlü, kendine güvenen, risk alan, yaratıcı, hedef odaklı, güvenilir, sabırlı, vizyon sahibi, insiyatif kullanan, disiplinli, planlayıcı kişisel özelliklerine sahip olması gerektiğini belirtmektedir. ICN girişimci hemşireyi, iş sağığı danışmanlığı yapılması, sağığın iyileştirilmesine yönelik proje üretilmesi, sağlık ürünlerinin geliştirilmesi, personel yönetimi, hemşirelik bakımı, yaşlı bakımı ve danışmanlık gibi doğrudan hemşirelik hizmetlerinin sunumunda yer alan hemşireler olarak tanımlamaktadır ${ }^{7}$.

Bilimsel, teknolojik ve kültürel değişimlerin çok hızlı gerçekleşmesi buna paralel olarak bilgideki değişimin sürekliliği ve hızı çağımız insanını sürekli öğrenme gereksinimi içinde bırakmaktadır ${ }^{8}$. Bu bağlamda, toplumlar bilinçli bir bilgi tüketicisi olmanın yanı sıra bilgi üretebilen bireylere gereksinim duymaktadır. Bu bireylerin aynı zamanda yaşam boyu öğrenme becerilerine sahip, sürekli olarak bilgisini yenileyen, değişime ayak uydurabilen ve gelişmeleri takip edebilen nitelikte olmaları beklenmektedir ${ }^{9}$. Kısaca, yaşam boyu öğrenme süreci bireylere yaşamlarında her an ihtiyaç duyabilecekleri bilgiye nasıl ulaşacaklarını öğretmelidir ${ }^{10}$.

Yaşam boyu öğrenme okul öncesi dönemde evde başlayan, sonrasında zorunlu örgün eğitim ve üniversite ile devam eden $^{11}$, sonraki dönemlerde iş yerinde ve toplumda bireylerin örgün eğitimin ötesinde kendi eğitimlerine devam ettikleri bir süreç olarak ifade edilmektedir ${ }^{11,12}$. Bireyin yeni bilgi keşfetme ya da inşa etme sürecine dahil olması için motivasyona sahip olması beklenmektedir ${ }^{13}$. Üniversiteler internet tabanlı eğitim, sanal üniversite ${ }^{14}$ ve e- öğrenme yoluyla ${ }^{15}$ yaşam boyu öğrenme etkinliklerine ve mesleki gelişime destek sağlamaktadırlar ${ }^{14}$. Toplumun sağlık bakım gereksinimlerini karşılayan, neyi, nasıl ve nereden öğreneceğini bilen, bilimsel araştırmalarla yeni bilgiler üretebilen özerk hemşirelerin yetiştirilmesinde hemşirelik eğitiminin ve çağdaş müfredat programlarının önemli olduğu ifade edilmektedir ${ }^{16}$. Hemşirelik uygulamaları için büyük öneme sahip olan yaşam boyu öğrenme; profesyonellerin yeni bilgiler ve sağlık hizmetleri ile ilgili gelişmelerden haberdar olmalarını sağlamaktadır. Tüm hemşireler, güvenli hemşirelik uygulamaları için gerekli tutum, bilgi ve becerileri geliştirmek ve sürdürmek için yaşam boyu öğrenen olma sorumluluğunu üstlenmelidir ${ }^{17}$.
Yapılan ulusal ve uluslararası literatür taraması sonucunda hemşirelik öğrencilerinin bireysel girişimcilik algıları ve yaşam boyu öğrenme eğilimleri arasındaki ilişkinin belirlenmesini inceleyen herhangi bir araştırmaya rastlanmamıştır. Gerçekleştirilen bu çalışmanın literatürdeki bu boşluğu doldurmaya katkı sağlayacağı düşünülmektedir. Bu çalışmadan elde edilen sonuçların bilimsel ve teknolojik gelişmeleri takip edebilen, sürekli olarak bilgisini yenileyebilen girişimci ve yaşam boyu öğrenen hemşirelerin yetiştirilmesinde benimsenecek ilkelerin oluşturulmasına yardımcı olacağı değerlendirilmektedir.

\section{Araştırmanın Amacı}

$\mathrm{Bu}$ araştırma, hemşirelik öğrencilerinin bireysel girişimcilik algıları ve yaşam boyu öğrenme eğilimleri arasındaki ilişkinin belirlenmesi amacıyla yapılmıştır.

\section{GEREÇ ve YÖNTEM}

\section{Araştırmanın Türü}

Bu araştırma, tanımlayıcı olarak yapılmıştır.

\section{Araştırma Evren ve Örneklemi}

Araştırma Türkiye'nin Kuzeydoğu Anadolu Bölgesi'nin (TRA1-Erzurum, Erzincan, Bayburt; TRA2-Ağrı, Kars, Ardahan, Iğdır) alt bölgesi olan TRA2'de bulunan bir ilde yer alan üniversitenin sağlık bilimleri fakültesi hemşirelik bölümünde gerçekleştirilmiştir. Araştırmanın evrenini, 2017-2018 Eğitim-Öğretim yılı bahar döneminde hemşirelik bölümünde öğrenim gören öğrenciler oluşturmaktadır. Hemşirelik bölümünde çalışmanın yapıldığı dönemde 1.sınıfta 185, 2. sınıfta 166, 3. sınıfta 169 ve 4. sınıfta 215 öğrenci olmak üzere toplam 735 öğrenci öğrenim görmektedir. Araştırmada örneklem seçimine gidilmemiş, tüm evrene ulaşılmaya çalışılmıştır. Araştırmanın yapıldığı gün ve saatte bazı öğrencilerin devamsızlık yapmaları, bazılarının ise çalışmaya katılmayı kabul etmemeleri nedenleriyle evrenin tamamına ulaşılamamıştır. Araştırma, gönüllü olarak çalışmaya katılmayı kabul eden toplam 529 öğrenci ile gerçekleştirilmiştir. Veri toplama süreci sona erdiğinde 6 öğrencinin formları eksik doldurduğu belirlenmiş ve bu öğrencilere ait anketler çalışma dışı bırakılarak veri değerlendirmesi 523 (\%71.2) öğrenci ile tamamlanmıştır.

\section{Veri Toplama Araçları}

"Tanıtıcı Bilgi Formu"nun orijinal hali konu ile ilgili literatür ışığında ${ }^{18-21}$ araştırmacılar tarafından hazırlanmış açık ve kapalı uçlu olmak üzere toplamda 21 sorudan (öğrencilerin cinsiyeti, yaşı, sınıfı, kaldığı yer vb.) oluşmaktadır. Bu çalışmada orijinal formdan 15 soru ile değerlendirme yapılmıştır. Yaşam Boyu Öğrenme Eğilimleri Ölçeği (YBÖEÖ) Coşkun tarafından 2009 yılında üniversite öğrencilerinde geliştirilmiş, geçerlilik ve güvenirlilik çalışması yapılmıştır. YBÖEÖ'de toplam 27 madde bulunmaktadır. Ölçek çok uyuyor (1), kısmen uyuyor (2), çok az uyuyor (3), çok az uymuyor (4), kısmen uymuyor (5), hiç uymuyor (6) şeklinde 6 'lı likert tipi derecelendirmeye sahiptir. Ölçekten alınabilecek minimum puan 27 ve maksimum puan 162 olarak belirlenmiştir. YBÖEÖ'nün alt boyutları sırasıyla motivasyon ( 6 madde; $1,2,3,4,5,6$ ), sebat ( 6 madde; 7,8 , $9,10,11,12$ ), öğrenmeyi düzenlemede yoksunluk ( 6 madde; $13,14,15,16,17,18$ ) ve merak yoksunluğu (9 madde; 19 , 
20, 21, 22, 23, 24, 25, 26, 27) olarak belirlenmiştir. YBÖEÖ'de puan arttıkça yaşam boyu öğrenme eğilimi artmaktadır. Ölçeğinin Cronbach $\alpha$ değeri $0.89^{\prime}$ dur $^{8}$. Bu çalışmada elde edilen Cronbach $\alpha$ değeri 0.89 olarak hesaplanmıştır. Bireysel Girişimcilik Algı Ölçeği (BGAÖ) ise İncik ve Uzun tarafından 2017 yılında üniversite öğrencilerinde geliştirilmiş, geçerlilik ve güvenirlilik çalışması yapılmıştır. Ölçekte toplam 31 madde bulunmaktadır. Ölçek kesinlikle katılıyorum (5), katılıyorum (4), kararsızım (3), katılmıyorum (2), kesinlikle katılmıyorum (1) şeklinde 5'li likert tipi derecelendirmeye sahiptir. Ölçekten alınabilecek minimum puan 31 ve maksimum puan 155 olarak belirlenmiştir. BGAÖ'nün alt boyutları sırasıyla planlama (6 madde; 1, 2, 3, $4,5,6)$, kontrol odağı (8 madde; $7,8,9,10,11,12,13,14$ ), kendine güven ( 6 madde; $15,16,17,18,19,20)$, iletişim (4 madde; 21, 22, 23, 24), motivasyon (4 madde; 25, 26, 27, 28) ve öz disiplin (3 madde; 29, 30, 31) olarak belirlenmiştir. BGAÖ'de puan artıkça bireysel girişimcilik algısı da aynı yönde artmaktadır. Ölçeğin Cronbach's $\alpha$ değeri $0.92^{\prime}$ dir $^{22}$. Bu çalışmada elde edilen Cronbach's $\alpha$ değeri 0.92 olarak hesaplanmıştır.

\section{Verilerin Toplama Araçlarının Uygulanması}

Araştırmanın ön uygulaması; aynı fakültenin ebelik bölümünde öğrenim gören örneklem grubu ile benzer özelliklere sahip 10 gönüllü öğrenci ile 9 Şubat 2018 tarihinde yapılmıştır. Ön uygulamada tanıtıcı bilgi formunun anlaşılırlığı test edilmiş olup ön uygulama sonucunda formda gerekli düzenlemeler yapılmıştır. Ayrıca ön uygulama sırasında veri toplama aracına başlama ve bitiş süresi kaydedilmiş ve bunun sonucunda veri toplama formunun yanıtlanması için gereken ortalama süre 15-20 dakika olarak hesaplanmıştır.

Araştırmanın uygulaması; hemşirelik bölümünde 01-07 Mart 2018 tarihleri arasında yapılmıştır. Veri toplama araçları uygulanmadan önce derslerin öğretim elemanları ile görüşülerek izin alınan tarih ve saatte uygulama gerçekleştirilmiştir. Veri toplama araçları öğrencilere ders sonrasında dağıtılmıştır. Temel meslek derslerinden sonra dikkat dağınıklığı olabileceğinden veri toplama araçları bu dersler dışında uygulanmıştır. Araştırmanın yapıldığı kurumda öğretim elemanı olarak çalışmayan araştırmacı tarafından sınıf ortamında dağıtılan veri toplama araçlarını dolduran öğrenciler araştırmacıya teslim etmişlerdir. Uygun olmayan öğrenciler veri toplama aracını sonrasında da teslim etme fırsatı bulmuşlardır. Araştırmaya katılmayı kabul eden tüm öğrencilere sınıfta "Tanıtıcı Bilgi Formu", "Bireysel Girişimcilik Algı Ölçeği-BGAÖ" ve "Yaşam Boyu Öğrenme Eğilimleri Ölçeği-YBÖEÖ” veri toplama araçlarından oluşan form dağıtılarak uygulanmıştır.

\section{Verilerin Değerlendirilmesi}

Araştırmadan elde edilen veriler, araştırmacılar tarafından SPSS 20.0 (Statistical Package for Social Science) paket programı kullanılarak bilgisayar ortamına aktarılarak değerlendirilmiştir. Öğrencilere ait tanıtıcı bilgi formunda yer alan soruların frekans ve yüzdeleri hesaplanmıştır. Her bir öğrenci için YBÖEÖ ve BGAÖ toplam puanlarının ve alt boyut toplam puanlarının tanımlayıcı istatistikleri hesaplanmıştır. Ölçeklerden alınan puanların bağımsız değişkenlere göre normal dağılım gösterip göstermedikleri Kolmogorov-Smirnov (KS) testi ile sınanmıştır. Normal dağılım göstermeyen verilerin analizinde non-parametrik testlerden Mann-Whitney $U$ ve Kruskal Wallis-H testleri kullanılmıştır. "Yaşam Boyu Öğrenme Eğilimi (YBÖE)" ile "Bireysel Girişimcilik Algı (BGA)" arasındaki ilişkinin varlığına ölçek toplam puanları normal dağılım göstermediğinden sperman korelasyon ile bakılmıştır. İstatistiksel testlerin anlamlılık düzeyi için $p<0.05$ değeri kabul edilmiştir ${ }^{23}$.

\section{Araştırmanın Etik Boyutu}

“BGAÖ”nün ve "YBÖEÖ”nün kullanılması için sorumlu yazarlardan yazılı izin, araştırmanın yürütülmesi için ilgili üniversitenin etik kurulundan 13 Aralık 2017 tarih ve 181 sayılı yazı ile etik kurul onayı alınmıştır. Araştırmanın gerçekleştirilmesi için Sağlık Bilimleri Fakültesi 31 Ocak 2018 tarih ve 10829923-030.99-E.4110 sayılı yazı ile izin vermiştir. Araştırmaya katılan tüm öğrencilere araştırma hakkında açıklama yapılarak bilgi verilmiş ve onamları alınmıştır.

\section{Araştırmanın Sınırlılıkları}

Araştırmadan elde edilen bulgular çalışmanın yapıldığı Sağlık Bilimleri Fakültesi Hemşirelik Bölümünde 2017-2018 bahar döneminde öğrenim gören öğrencilere genellenebilir.

\section{BULGULAR}

Tablo 1 incelendiğinde; hemşirelik öğrencilerinin yaş ortalamasının 20.99 \pm 2.05 (min: 17; max: 35 ) olduğu, \% 30 'unun 1. sınıfta ve \% 28.5'inin 2. sınıfta olduğu, \%57.7'sinin kadın olduğu, \% 98.5'inin bekâr olduğu, $\% 61.4$ 'ünün Anadolu lisesinden mezun olduğu, \%66.5'inin öğrenci yurdunda kaldığı, \%55.6'sının ailesinin aylık gelirinin giderine eşit olduğu belirlenmiştir. Ayrıca hemşirelik öğrencilerinin ailesinin aylık geliri giderine eşit olanlarda YBÖEÖ, geliri giderinden fazla olanlarda ise BGAÖ toplam ortanca puanlarının daha yüksek olduğu saptanmıştır $(p<0.05)$.

Ayrıca, hemşirelik öğrencilerinin bazı değişkenlere göre BGAÖ puanları ve YBÖEÖ puanları dağılımı Tablo 2'de yer almaktadır. Tablo incelendiğinde; hemşirelik öğrencilerinde mezuniyet sonrası kariyer planı olarak lisansüstü eğitim yapmak isteyenlerde BGAÖ, eğitimci olmak isteyenlerde YBÖEÖ ortanca puanlarının daha yüksek olduğu $(p<0.05)$ saptanmıştır. Çalışmada hemşirelik öğrencilerinde düzenli kitap okuma alışkanlığı olanlarda hem YBÖEÖ hem de BGAÖ ortanca puanlarının anlamlı derecede daha yüksek olduğu belirlenmiştir $(p<0.05)$.

Hemşirelik öğrencilerinin BGAÖ toplam ve alt boyut puan ortalamalarının dağılımı Tablo 3.'de gösterilmiştir. BGAÖ toplam puan ortalaması $119.98 \pm 15.30$ olarak bulunmuştur. BGAÖ alt boyutlarına ilişkin puan ortalamalarının en yüksek kontrol odağı $31.29 \pm 4.49$, en düşük ise öz disiplin $11.26 \pm 2.18$ alt boyutlarında alındığı saptanmıştır.

Hemşirelik öğrencilerinin YBÖEÖ toplam ve alt boyut puan ortalamalarının dağııımı Tablo 4'de verilmiştir. YBÖEÖ'nün toplam puan ortalaması $80.80 \pm 20.62$ olarak bulunmuştur. YBÖEÖ alt boyutlarına ilişkin puan ortalamalarının en yüksek merak yoksunluğu $32.37 \pm 11.96$, en düşük ise motivasyon $11.37 \pm 4.16$ alt boyutlarında alındığı belirlenmiştir.

BGAÖ ile YBÖEÖ toplam puanları arasında negatif yönlü zayıf anlamlı bir ilişki bulunmuştur $(p<0.001, r=-0.164)$ 
Tablo 1. Hemşirelik Öğrencilerinin Tanıtıcı Bilgilerine Göre YBÖEÖ Puanları ve BGAÖ Puanları Dağılımı ( $n=523)$

\begin{tabular}{|c|c|c|c|c|c|}
\hline \multirow[b]{2}{*}{ Taniticı Bilgiler } & \multirow[b]{2}{*}{$n(\%)$} & \multicolumn{2}{|c|}{ YBÖEÖ } & \multicolumn{2}{|c|}{ BGAÖ } \\
\hline & & Min.-Maks. & \multirow[t]{2}{*}{$\begin{array}{c}\text { Median } \\
\text { [25-75. Yüzdelik]* }\end{array}$} & Min.-Maks. & \multirow[t]{2}{*}{$\begin{array}{c}\text { Median } \\
\text { [25-75. Yüzdelik]* } \\
\end{array}$} \\
\hline Yaş ortalaması & $20.99 \pm 2.05$ (min:17; maks: & & & & \\
\hline \multicolumn{6}{|l|}{ Sinif } \\
\hline 1.sinif & $157(30.0)$ & $32-117$ & 89 [71-98] & $70-151$ & $123[113-132]$ \\
\hline $2 . \operatorname{sinif}$ & $149(28.5)$ & $27-122$ & 85 [66-97] & $83-150$ & $121[113-131.5]$ \\
\hline $3 . \sin \mathrm{if}$ & $103(19.7)$ & $33-119$ & 82 [63-92] & $69-155$ & $117[105-127]$ \\
\hline $4 . \operatorname{sinif}$ & $114(21.8)$ & $27-120$ & $83[66.75-98.25]$ & $79-155$ & $120[113-126]$ \\
\hline Test** & & \multicolumn{2}{|l|}{$\mathrm{p}=0.259 ; \mathrm{KW}=4.024$} & \multicolumn{2}{|l|}{$\mathrm{p}=0.103 ; \mathrm{KW}=6.173$} \\
\hline \multicolumn{6}{|l|}{ Cinsiyet } \\
\hline Kadın & $302(57.7)$ & $27-122$ & 89 [70-99] & $70-153$ & 120 [110.75-128] \\
\hline Erkek & $221(42.3)$ & $27-120$ & 79 [62.5-92] & $69-155$ & $122[112-132]$ \\
\hline Test** & & \multicolumn{2}{|l|}{$\begin{array}{l}p=0.001 \\
z=-4.606\end{array}$} & \multicolumn{2}{|l|}{$\begin{array}{l}p=0.099 \\
z=-1.648\end{array}$} \\
\hline \multicolumn{6}{|l|}{ Medeni Durum } \\
\hline Evli & $8(1.5)$ & $27-100$ & $76.5[40-93.25]$ & $113-149$ & $123.5[119.75-137.75]$ \\
\hline Bekâr & $515(98.5)$ & $27-122$ & 85 [67-97] & $69-155$ & $121[112-130]$ \\
\hline Test** & & \multicolumn{2}{|l|}{$\begin{array}{l}p=0.215 \\
z=-1.239\end{array}$} & \multicolumn{2}{|l|}{$\begin{array}{l}\mathrm{p}=0.177 \\
\mathrm{z}=-1.349\end{array}$} \\
\hline \multicolumn{6}{|l|}{ Mezun Olduğunuz Okul Türü } \\
\hline Anadolu Lisesi & $321(61.4)$ & $27-122$ & 85 [67-97] & $73-155$ & 119 [112-128] \\
\hline Sağlık Meslek Lisesi & $13(2.5)$ & $51-102$ & 94 [87.5-99] & $95-150$ & $126[115-137]$ \\
\hline Genel Lise & $140(26.8)$ & $33-120$ & $83[66.25-95.75]$ & $69-153$ & 123 [111.25-132] \\
\hline Diğer (fen lisesi, ön lisans vb.) & $49(9.3)$ & $27-117$ & 89 [76-99] & $70-155$ & $123[111.5-134]$ \\
\hline Test** & & \multicolumn{2}{|l|}{$\begin{array}{l}p=0.159 \\
K W=5.177\end{array}$} & \multicolumn{2}{|l|}{$\begin{array}{l}p=0.150 \\
K W=5.312\end{array}$} \\
\hline \multicolumn{6}{|l|}{ Öğrencilikte Kalınan Yer } \\
\hline Öğrenci yurdu & $348(66.5)$ & $27-122$ & $87[69-97.75]$ & $69-155$ & $120.5[111.25-131]$ \\
\hline Evde ailesiyle & $41(7.8)$ & $27-112$ & 90 [72.5-98.5] & $80-149$ & $124[112-130.5]$ \\
\hline Evde arkadaşla & $126(24.1)$ & $35-120$ & $78.5[59.75-94]$ & $73-155$ & $120[112-129]$ \\
\hline Diğer & $8(1.6)$ & $48-111$ & 81 [65-95.5] & $100-146$ & $118[107.5-130]$ \\
\hline Test** & & \multicolumn{2}{|l|}{$\begin{array}{l}\mathbf{p}=\mathbf{0 . 0 4 9} \\
\mathrm{KW}=7.875\end{array}$} & \multicolumn{2}{|l|}{$\begin{array}{l}\mathrm{p}=0.897 \\
\mathrm{KW}=0.598\end{array}$} \\
\hline \multicolumn{6}{|l|}{ Ailenin Aylık Gelir Durumu } \\
\hline Gelir giderden fazla & $72(13.8)$ & $36-119$ & 75.5 [57-96] & $69-150$ & 125 [116.5-134] \\
\hline Gelir gidere eşit & $291(55.6)$ & $27-122$ & 88 [71-97] & $70-155$ & $120[110-128]$ \\
\hline Gelir giderden az & $160(30.6)$ & $27-118$ & 83.5 [64-96] & $74-155$ & 119 [112.25-132] \\
\hline Test** & & \multicolumn{2}{|l|}{$\begin{array}{l}\mathbf{p}=\mathbf{0 . 0 2 9} \\
\mathrm{KW}=7.094\end{array}$} & $\begin{array}{l}\mathbf{p}=\mathbf{0 . 0 1 1} \\
\mathrm{KW}=9.040\end{array}$ & \\
\hline Hemşirelik Bölümünü İsteyere & urumu & & & & \\
\hline Evet & $347(66.3)$ & $27-119$ & 87 [67-97] & $70-153$ & $122[114-131]$ \\
\hline Hayır & $176(33.7)$ & $33-122$ & $83[67-96.75]$ & $69-155$ & 116 [106-128.5] \\
\hline Test** & & $\begin{array}{l}p=0.467 \\
Z=-0.727\end{array}$ & & $\begin{array}{l}\mathrm{p}=0.001 \\
\mathrm{z}=-3.321\end{array}$ & \\
\hline Hemşirelik Bölümü Okumakta & n Olma Durumu & & & & \\
\hline Evet & $346(66.2)$ & $27-122$ & 87 [68-97.25] & $70-153$ & $122.5[114-131]$ \\
\hline Hayır & $177(33.8)$ & $30-120$ & 83 [66-95] & $69-155$ & 115 [104-127] \\
\hline Test** & & $\begin{array}{l}\mathrm{p}=0.183 \\
\mathrm{Z}=-1.332\end{array}$ & & $\begin{array}{l}\mathrm{p}=\mathbf{0 . 0 0 1} \\
\mathrm{z}=-4.644\end{array}$ & \\
\hline
\end{tabular}


Tablo 2. Hemşirelik Öğrencilerinin Bazı Değişkenlere Göre YBÖEÖ Puanları ve BGAÖ Puanları Dağılımı ( $n=523)$

\begin{tabular}{|c|c|c|c|c|c|}
\hline \multirow[b]{2}{*}{ Değişkenler } & \multirow[b]{2}{*}{$n(\%)$} & \multicolumn{2}{|c|}{ YBÖEÖ } & \multicolumn{2}{|c|}{ BGAÖ } \\
\hline & & Min.-Max & $\begin{array}{c}\text { Median } \\
\text { [25-75. Yüzdelik]* }\end{array}$ & Min.-Max. & $\begin{array}{c}\text { Median } \\
\text { [25-75. Yüzdelik]* }\end{array}$ \\
\hline \multicolumn{6}{|c|}{ Mezuniyet Sonrası Kariyer Planı } \\
\hline \multicolumn{6}{|c|}{ Lisansüstü Eğitim Yapmak } \\
\hline Evet & $229(43.8)$ & $33-119$ & 87 [68.5-97.5] & $69-155$ & 123 [114.5-132] \\
\hline Hayır & $294(56.2)$ & $27-122$ & $83[67-96]$ & $70-155$ & 119 [108.75-128] \\
\hline Test** & & \multicolumn{2}{|l|}{$\mathrm{p}=0.186 ; \mathrm{Z}=-1.324$} & \multicolumn{2}{|l|}{$\mathrm{p}=0.001 ; \mathrm{Z}=-3.388$} \\
\hline \multicolumn{6}{|c|}{ Kamuda Hemşire Olarak Çalışmak } \\
\hline Evet & $311(59.5)$ & $27-122$ & $87[70-97]$ & $73-155$ & 121 [111-128] \\
\hline Hayır & $212(40.5)$ & $30-119$ & $85[61.25-96]$ & $69-155$ & $121[113-132]$ \\
\hline Test** & & \multicolumn{2}{|l|}{$\mathrm{p}=0.083 ; \mathrm{z}=-1.734$} & \multicolumn{2}{|l|}{$\mathrm{p}=0.254 ; \mathrm{z}=-1.141$} \\
\hline \multicolumn{6}{|l|}{ Eğitimci Olmak } \\
\hline Evet & $113(21.6)$ & $30-116$ & 91 [74.5-98.5] & $74-151$ & $123[114-131]$ \\
\hline Hayır & $410(78.4)$ & $27-122$ & $83.5[65-95]$ & $69-155$ & 120 [111-130.25] \\
\hline Test** & & \multicolumn{2}{|l|}{$\mathrm{p}=0.007 ; \mathrm{Z}=-2.677$} & \multicolumn{2}{|l|}{$\mathrm{p}=0.088 ; \mathrm{Z}=-1.706$} \\
\hline \multicolumn{6}{|l|}{ Yönetici Olmak } \\
\hline Evet & $59(11.3)$ & $32-116$ & 85 [77-99] & $88-151$ & $122[114-132]$ \\
\hline Hayır & $464(88.7)$ & $27-122$ & 85 [66.25-96] & $69-155$ & $120[112-130.75]$ \\
\hline Test** & & \multicolumn{2}{|l|}{$\mathrm{p}=0.203 ; \mathrm{Z}=-1.274$} & \multicolumn{2}{|l|}{$\mathrm{p}=0.234 ; \mathrm{Z}=-1.190$} \\
\hline \multicolumn{6}{|c|}{ Eğitim Süresince Geliri Karşılama Durumu } \\
\hline Aileden & $110(21.0$ & $27-120$ & 85 [61.75-98] & $69-155$ & $119[107.75-128]$ \\
\hline Burslardan & $122(23.4)$ & $33-122$ & $88[70.75-96]$ & $70-155$ & $122.5[111.75-133]$ \\
\hline Aile ve Burs & $237(45.3)$ & $27-119$ & 84 [68-97] & $73-153$ & $120[112-127]$ \\
\hline Çalışarak & $21(4.0)$ & $35-107$ & 88 [50.5-97] & $91-148$ & $125[113.5-137.5]$ \\
\hline Çalışarak ve Aile & $9(1.7)$ & 63-101 & 89 [76.5-96.5] & $98-138$ & 113 [104.5-119] \\
\hline Çalışarak ve Burs & $24(4.6)$ & $32-107$ & 81 [54-96] & $89-155$ & $127[118.25-133.75]$ \\
\hline Test** & & \multicolumn{2}{|l|}{$\mathrm{p}=0.818 ; \mathrm{KW}=2.220$} & \multicolumn{2}{|l|}{$p=0.015 ; k W=14.029$} \\
\hline \multicolumn{6}{|c|}{ Sosyal Etkinliğe Katılma Durumu } \\
\hline Yeterli & $96(18.4)$ & $35-114$ & $84.5[67.25-96.75]$ & $73-155$ & 125 [113-132] \\
\hline Kısmen Yeterli & $239(45.7)$ & $32-118$ & $83[65-96]$ & $69-155$ & $121[114-130]$ \\
\hline Yetersiz & 188(35.9) & $27-122$ & 87 [69.25-97.75] & $70-155$ & $118[107.25-128]$ \\
\hline Test** & & \multicolumn{2}{|l|}{$\begin{array}{l}\mathrm{p}=0.462 \\
\mathrm{KW}=1.543\end{array}$} & \multicolumn{2}{|l|}{$\begin{array}{l}p=0.011 \\
K W=9.004\end{array}$} \\
\hline \multicolumn{6}{|c|}{ Herhangi bir Kulübe Üyelik Durumu } \\
\hline Var & $42(8.0)$ & $27-114$ & 76 [69.75-93.25] & $69-149$ & $119.5[108.25-132]$ \\
\hline Yok & $481(92.0)$ & $27-122$ & 86 [67-97] & $70-155$ & $121[112-130.5]$ \\
\hline Test $^{* *}$ & & $\begin{array}{l}p=0.298 \\
Z=-1.040\end{array}$ & & $\begin{array}{l}p=0.794 \\
z=-0.261\end{array}$ & \\
\hline Düzenli Kitap Okuma Alış & & & & & \\
\hline Evet & $181(34.6)$ & $30-120$ & 89 [70-99] & $70-155$ & 124 [114-133] \\
\hline Hayır & $342(65.4)$ & $27-122$ & 83.5 [66-95] & $69-155$ & 119 [110-128] \\
\hline Test** & & $\begin{array}{l}\mathrm{p}=0.026 \\
\mathrm{Z}=-2.228\end{array}$ & & $\begin{array}{l}\mathrm{p}=0.002 \\
\mathrm{z}=-3.062\end{array}$ & \\
\hline Girişimciliğe Yönelik Hert & tkinliğe Katılma D & rumu & & & \\
\hline Evet & $128(24.5)$ & $33-122$ & 90 [65.5-97.75] & $70-155$ & $124.5[115-133]$ \\
\hline Hayır & $395(75.5)$ & $27-120$ & 84 [67-96] & $69-155$ & $120[111-128]$ \\
\hline Test** & & $\begin{array}{l}p=0.336 \\
z=-0.962\end{array}$ & & $\begin{array}{l}p=0.007 \\
z=-2.721\end{array}$ & \\
\hline
\end{tabular}


Tablo 3. Hemşirelik Öğrencilerinin BGAÖ Toplam ve Alt Boyut Puan Ortalamalarının Dağılımı ( $n=523$ )

\begin{tabular}{|c|c|c|}
\hline Alt Boyutlar & $\mathrm{X} \pm \mathrm{SS} *$ & Min -Maks. \\
\hline Kontrol Odağı & $31.29 \pm 4.49$ & $13.00-40.00$ \\
\hline Kendine Güven & $23.81 \pm 3.55$ & $12.00-30.00$ \\
\hline Planlama & $22.79 \pm 3.61$ & $11.00-30.00$ \\
\hline İletişim & $15.66 \pm 2.39$ & $5.00-20.00$ \\
\hline Motivasyon & $15.14 \pm 2.70$ & $7.00-20.00$ \\
\hline Öz Disiplin & $11.26 \pm 2.18$ & $4.00-15.00$ \\
\hline BGAÖ Toplam & $119.98 \pm 15.30$ & $69.00-155.00$ \\
\hline
\end{tabular}

*SS: Standart Sapma,

Tablo 4. Hemşirelik Öğrencilerinin YBÖEÖ Toplam ve Alt Boyut Puan Ortalamalarının Dağılımı ( $n=523$ )

\begin{tabular}{|l|c|c|}
\hline \multicolumn{1}{|c|}{ Alt Boyutlar } & $\mathbf{X} \pm$ SS* & Min.-Maks \\
\hline $\begin{array}{l}\text { Merak } \\
\text { Yoksunluğu }\end{array}$ & $32.37 \pm 11.96$ & $9.00-54.00$ \\
\hline $\begin{array}{l}\text { Öğrenmeyi } \\
\text { Düzenlemede } \\
\text { Yoksunluk }\end{array}$ & $22.80 \pm 8.57$ & $6.00-36.00$ \\
\hline Sebat & $14.25 \pm 5.18$ & $6.00-34.00$ \\
\hline Motivasyon & $11.37 \pm 4.16$ & $6.00-30.00$ \\
\hline YBÖEÖ Toplam & $\mathbf{8 0 . 8 0 \pm 2 0 . 6 2}$ & $\mathbf{2 7 . 0 0 - 1 2 2 . 0 0}$ \\
\hline
\end{tabular}

*SS: Standart Sapma,

\section{TARTIŞMA}

Yapılan çalışmada YBÖE'nin kadın öğrencilerde anlamlı derecede daha yüksek olduğu, buna karşılık BGA'nın ise erkeklerde daha yüksek olduğu bulunmuştur. Literatür incelendiğinde Coşkun ve ark. (2012), Kılıç (2014), Ilıman (2017), Karaduman ve ark. (2017), Pesen ve ark. (2017), Çetin ve Çetin (2018) yaptıkları araştırmalara göre kadın öğrencilerin YBÖE'lerinin erkek öğrencilerden yüksek olduğu belirlenmiştir8,24-28. Denat ve ark. (2016), Dikmen ve ark. (2017), Ekşioğlu ve ark. (2017) yaptığı araştırmalara göre ise erkek öğrencilerin YBÖE'lerinin kadın öğrencilere göre yüksek olduğu tespit edilmiştir ${ }^{19,29,30}$. Çalışmadan ve yapılan araştırmalardan elde edilen sonuçlar doğrultusunda bu bulgunun kadınların öğrenme isteklerinin ve merak duygularının erkeklere göre daha fazla olmasından kaynaklandığı düşünülmektedir.

Evde ailesiyle kalan öğrencilerde hem YBÖE'nin hem de BGA'nın daha yüksek olduğu saptanmıştır. Çalışma sonucu ile paralel olarak Arslan'ın (2017) yaptığı çalışmada ailesiyle kalan öğrencilerin YBÖE'lerinin öğrenci evinde kalan öğrencilere göre daha yüksek olduğu belirlenmiştir ${ }^{31}$. Ailesiyle birlikte yaşayan öğrencilerin evde ebeveyn davranışlarını örnek almasının ve temel gereksinimler ile ilgili sorumluluklarının az olmasının öğrenmeye eğilimlerinin yüksek olmasında etkili olduğu değerlendirilmektedir.

Ailesinin aylık geliri giderine eşit olan öğrencilerde YBÖE'nin, ailenin aylık geliri giderinden fazla olan öğrencilerde ise BGA'nın daha yüksek olduğu bulunmuştur. Tunca ve ark. (2015), öğretmen adaylarında yaptıkları araştırmada aylık geçim gideri yüksek olan öğretmen adaylarının YBÖE'lerinin daha yüksek olduğunu tespit etmiştir ${ }^{32}$. Denat ve ark. (2016) hemşirelik öğrencilerinde yaptığı çalışmada ise gelir durumunun YBÖE düzeyini etkilemediğini saptamıştır ${ }^{19}$. Bununla birlikte Arslan (2002), Çelik ve ark. (2014),
Dashdamırova (2019) yaptıkları araştırmalarda ailesinin aylık geliri fazla olan öğrencilerde girişimciliğin daha yüksek olduğu ifade edilmiştir ${ }^{33-35}$. Doğan (2015), Eminoğlu (2016), Özbay (2016), Balkaya (2017), Karakulle ve ark. (2017), araştırmalarında ise ailesinin aylık gelirinin öğrencilerin girişimcilik düzeyini etkilemediğini saptamıştır ${ }^{36-40}$. Maddi harcamanın ve olanakların kısıtlı olduğu durumlarda bireysel çaba ve isteğin artacağı ve bununda YBÖE'yi artırabileceği düşünülmektedir. Buna karşılık aile gelirinin fazla olması durumunda ise girişimcilik için risk alma ve kendine güvenme konusunda alınacak desteğin artması bireyin girişimci olma eğilimine pozitif katkı sağlayacağından BGA'yı artırabileceği değerlendirilmektedir.

Çalışmada hemşirelik bölümünü isteyerek seçenlerde ve hemşirelik bölümünü okumaktan memnun olanlarda YBÖE'nin ve BGA'nın daha yüksek olduğu saptanmıştır. Literatür incelendiğinde hemşirelik bölümünü isteyerek seçme, bölümü okumaktan memnun olma ve hemşirelik mesleğini kendi isteği ile tercih etme bağımsız değişkenlerini ele alan konu ile ilgili herhangi bir araştırmaya rastlanmamıştır. Hemşirelik öğrencilerinin bölümü isteyerek seçmeleri ve bölümü okumaktan memnun olmaları; meslekle ilgili teknolojik gelişmeleri ve yenilikleri yakından takip etmelerine, öz güvenlerinin artmasına, hastalarına kaliteli ve kanıta dayalı bakım sunmalarına neden olabilmektedir. Bu sebeplerle yeniliklere daha kolay ve hızlı motive olmaları mümkün olacak dolayısıyla yaşam boyu öğrenme eğilimlerinin ve girişimciliklerinin artması beklenen bir durum haline gelecektir. Ayrıca bu bireylerin profesyonel bir meslek üyesi olarak bakım ve tedavi rollerini daha etkili bir şekilde yerine getireceklerine ve yüklendiği mesleki sorumluluk bilinci ile bireysel gelişimine yönelik daha fazla çaba göstereceklerine inanılmaktadır.

Hemşirelik öğrencilerinde mezuniyet sonrası kariyer planı olarak lisansüstü eğitim yapmak ve eğitimci olmak isteyenlerde YBÖE'nin daha yüksek olduğu saptanmıştır. BGAÖ ortanca puanlarının da hem lisansüstü eğitim yapmak isteyenlerde hem de eğitimci olmak isteyenlerde daha yüksek olduğu ancak bu defa lisansüstü eğitim yapmak isteyen grup ile istemeyen grup arasında anlamlı farklılık olduğu belirlenmiştir ( $p<0.05)$. Türkmen ve ark. (2014), özel sektörde devam etmek isteyen öğrencilerin BGA'larını kamuda devam etmek isteyen öğrencilere göre daha yüksek bulmuştur ${ }^{41}$. Ekici (2016), yaptığı çalışmada kariyer hedeflerinden kendi işini kurmak isteyenlerin girişimcilik eğilimleri diğer kariyer hedefi belirleyenlere göre daha yüksek çıkmıştır ${ }^{42}$. Dolu ve ark. (2016) ve Ayar (2019) yaptıkları çalışmalarda mezuniyet sonrası kariyer planlaması ile girişimcilik arasında anlamlı bir ilişki olmadığını saptamıştır ${ }^{20,43}$. Ilıman (2017) yaptığı araştırmada mezuniyet sonrası eğitimin yapılması gerektiğini düşünen hemşirelik öğrencilerinde düşünmeyenlere göre YBÖE'nin daha yüksek olduğunu bulmuştur ${ }^{25}$. Akademik kariyer edinmenin eleştirel düşünme, bilimsel araştırma yaparak bilgi üretme, değerlendirme ve yorumlama, sentezlere ulaşmak için gerekli adımları belirleme iyi bir girişimci olmak için gerekli görülmektedir. Eğitim durumunun artmasıyla bilgi düzeyinin artması ve daha fazla öğrenmeye istekli olunması dolayısıyla öğrenilen bu bilgilerinde başkalarına 
aktarımının sağlanması için eğitimci olmak isteğinin fazla olduğu düşünülmektedir.

Hemşirelik öğrencilerinde eğitim süresince gelirini çalışarak ve aileden karşılayanlarda YBÖE'nin, gelirini çalışarak ve burslardan karşılayanlarda ise BGA'nın daha yüksek olduğu bulunmuştur. Korkmaz (2012) yaptığı çalışmada yaşamlarını çalışarak sürdüren öğrencilerin girişimciliğe daha yatkın olduğunu saptamıştır ${ }^{44}$. Bu sonuç öğrencilerin çalışarak maddi gelir elde etmesinin hem YBÖE'lerini hem de BGA'larını artırdığı şeklinde yorumlanabilir. Tamamen aileden bağımsız kendi gelirini elde eden öğrencilerin BGA'larının anlamlı derede yüksek olması beklenen bir sonuçtur. Öğrencilerin gelir durumunun artması kendine güveni artırmaya, duruma göre planlama yapmaya ve fikir yürütmeye yardımcı olmakta, bu durumda öğrencilerin mezun olduktan sonra girişimci olmasını kolaylaştırmakta yardımcı olarak görülmektedir.

Hemşirelik öğrencilerinden sosyal etkinliğe katılma durumunu yetersiz olarak ifade edenlerde YBÖE'nin, yeterli olarak ifade edenlerde ise BGA'nın daha yüksek olduğu saptanmıştır. Hemşirelik öğrencilerinden sosyal etkinliğe katılanların daha fazla birey ile iletişim kurduğu bununla birlikte farklı görüş ve fikirlerin konuşulduğu ortamlarda bulunma fırsatı yakaladıkları için BGA'larının daha yüksek olması beklenen bir sonuçtur.

Çalışmada hemşirelik öğrencilerinde düzenli kitap okuma alışkanlığı olanlarda hem YBÖE'nin hem de BGA'nın daha yüksek olduğu belirlenmiştir. Denat ve ark. (2016), Karaduman ve ark. (2017) yaptıkları araştırmalara göre kitap okuma alışkanlığı olan öğrencilerin YBÖE’lerinin okuma alışkanlığı olmayan öğrencilere göre daha yüksek olduğunu saptamışlardır ${ }^{19,26}$. Kitap okuma alışkanlığının profesyonel bir meslek üyesi olma yolunda ilerlerken bilgi birikimini artırdığı, farklı bakış açıları kazandırdığı, güçlüklerle ve stresle baş etmeyi kolaylaştırdığı, özgüven ve iletişime açık olma yönlerini pozitif yönde desteklediği düşünülmektedir. Bununla birlikte kitap okuma alışkanlığının bireylerde merak duygusunu, yaşam boyu öğrenme isteğini artırdığı ve ufkunu genişlettiği de değerlendirilmektedir.

Hemşirelik öğrencilerinden girişimciliğe yönelik herhangi bir ders/kurs vb. etkinliğe katılanlarda YBÖE'nin ve BGA'nın daha yüksek olduğu belirlenmiştir. Lee ve ark. (2005), Basu ve Virick (2008), Yanıkkerem ve ark. (2019) yaptıkları araştırmalarda öğrencilerden girişimcilikle ilgili ders alanların girişimciliğinin daha yüksek olduğunu saptamışlardır ${ }^{45-47}$. Girişimcilik ile ilgili alınan ders ve kursların girişimcilik eğilimi olan kişilerin daha özgüven sahibi, risk alabilen, yenilikçi düşünebilen, sosyal ve kendi işlerini kurabilen bireyler olmasına katkı sağlayacağı düşünülmektedir.

Çalışmadan elde edilen bulgular sonucunda hemşirelik öğrencilerinin bireysel girişimcilik algı düzeylerinin orta düzeyde olduğu söylenebilir. Çalışmaya katılan hemşirelik öğrencilerinin BGA ölçeğinde en yüksek puanı "Kontrol Odağı" alt boyutundan, en düşük puanı ise "Öz Disiplin" alt boyutundan aldıkları belirlenmiştir. Literatürde aynı ölçeği kullanan başka araştırmalara rastlanılmazken farklı BGAÖ kullanan araştırmalar bulunmaktadır. Bahar ve ark. (2018), ile Dolu ve ark. (2016) hemşirelik öğrencilerinde yaptıkları araştırmalarda ayrıca Akçakanat ve ark. (2014) üniversite öğrencilerinde yaptığı araştırmada BGA toplam puan ortalamasını bu çalışmadan daha yüksek olduğu görülmektedir. Bahsi geçen araştırmalarda elde edilen sonuç "girişimcilik düzeyi yüksek" şeklinde yorumlanmıştır ${ }^{8,20,21}$. Yapılmış olan diğer araştırmalarda ölçek alt boyutlarının yer almaması nedeniyle bu yönde bir karşılaştırma yapılamamıştır.

Çalışmada hemşirelik öğrencilerinin yaşam boyu öğrenme eğilimi düzeylerinin istenilen düzeyde olmadığı düşük olduğu görülmektedir. Çalışmaya katılan hemşirelik öğrencilerinin YBÖE ölçeğinde en yüksek puanı "Merak Yoksunluğu" alt boyutundan, en düşük puanı ise "Motivasyon" alt boyutundan aldıkları belirlenmiştir. Literatürde benzer sonuçları içeren araştırmalar mevcuttur. Tunca ve ark. (2015), öğretmen adaylarında yaptığı araştırmada YBÖE'nin yapılan bu çalışmaya göre daha düşük olduğu belirlenirken, alt boyutlarda en yüksek puan ortalamasını "Merak Yoksunluğu" boyutunda, en düşük puan ortalamasını ise "Motivasyon" alt boyutunda bulmuştur ${ }^{32}$. Coşkun ve Demirel (2012) üniversite öğrencilerinde yaptığı araştırmada YBÖE'nin yapılan bu çalışmaya göre daha yüksek olduğu saptanırken alt boyutlarda en yüksek puan ortalamasını "Merak Yoksunluğu" boyutunda, en düşük puan ortalamasını ise "Motivasyon" alt boyutunda aldıklarını belirlemiştir8. Literatürde çalışmada elde edilen sonuçlardan daha düşük YBÖE'ne sahip olan araştırmalarda bulunmaktadır. Arslan (2017) paramedik öğrencilerinde, Dikmen (2017) tıp fakültesi öğrencilerinde, Ekşioğlu ve ark. (2017) tarafından pedagojik formasyon öğrencilerinde ve Denat ve ark. (2006) hemşirelik öğrencilerinde gerçekleştirdikleri araştırmalarda YBÖE toplam puan ortalamasını bu çalışmaya göre daha düşük saptamışlardır ${ }^{19,29-31}$. Ayrıca literatürde YBÖE toplam puan ortalamasının daha yüksek olduğu çalışmalarda yer almaktadır ${ }^{25}$. Sonuçların bu şekilde farklılık göstermesinin nedeni olarak, öğrencilerin sosyo-demografik özelliklerinin ve öğrenim gördükleri bölümlerin farklı olması gösterilebilir. $B G A$ ve YBÖE arasında negatif yönlü anlamlı zayıf ilişki bulunmuştur. Literatürde BGA ile YBÖE arasındaki ilişkiyi inceleyen farklı araştırmalara rastlanılmamıştır. Ailenin aylık gelir durumu YВÖEÖ'de geliri giderine eşit olanlarda, BGAÖ'de ise geliri giderinden fazla olanlarda anlamlı derecede daha yüksek saptanmıştır. Bununla birlikte düzenli kitap okuma alışkanlığı olanlarda hem BGAÖ hem de YBÖEÖ puanlarının anlamlı derecede daha yüksek olduğu belirlenmiştir. Aylık gelir durumu ve düzenli kitap okuma alışkanlığı dışındaki değişkenlerin ise zıt yönde anlamlı derecede farklı olduğu görülmektedir. Değişkenler arasındaki ters yönlü ilişki girişimci kişilerin, disiplinli, risk alabilen ve hedef odaklı olarak çalıştıkları göz önüne alındığında ortaya çıkması beklenen bir durumdur. Bu noktadan hareketle böyle düşünen kişiler YBÖE için yürütülen etkinliklere katılmayı ya da bunun için bireysel çaba harcamayı zaman kaybı olarak görüyor olabilirler. 


\section{SONUÇ ve ÖNERILER}

Gerçekleştirilen bu çalışmada bireysel girişimcilik algıları yüksek olan hemşirelik öğrencilerinin yaşam boyu öğrenme eğilimlerinin daha düşük olduğu sonucuna ulaşılmıştır $(p<0.001, r=-0.164)$.

Yapılan bu çalışmadan elde edilen sonuçlar doğrultusunda; hemşirelik öğrencilerine bilimsel araştırma proje ödevlerinin verilmesi ve bu ödevlerin etkinliğinin değerlendirilmesi, hemşirelik lisans eğitiminde öğrencilerin yaşam boyu öğrenme eğilimlerini ve bireysel girişimciliğini artırmaya yönelik seçmeli derslere yer verilmesi, öğrencilerin bireysel girişimcilik algısını ve yaşam boyu öğrenme eğilimlerini etkileyen diğer faktörleri belirlemek amacıyla daha geniş gruplarda araştırma yapılması önerilmektedir.

Etik Kurul Onayı (Kurul adı, tarih ve sayı no): Kafkas Üniversitesi Tıp Fakültesi Etik Kurul Başkanlığı, 13 Aralık 2017 tarih ve 181 sayılı yazı ile etik kurul onayı alınmıştır. Çıkar Çatışması: Herhangi bir çıkar çatışması yoktur.

Finansal Destek: Bu çalışma için herhangi bir kurumdan ya da kişiden finansal destek alınmamıştır.

Katılımcı Onamı: Araştırmaya katılan tüm öğrencilere araştırma hakkında açıklama yapılarak bilgi verilmiş ve onamları alınmıştır.

Yazar Katkıları:

Araştırma dizaynı: FK, AKA

Veri toplama ve analizi: FK, AKA

Literatür araştırması: FK, AKA

Makale yazımı: FK, AKA

Teşekkür: Yazarlar, çalışmaya katılan Sağlık Bilimleri Fakültesi Hemşirelik Bölümü öğrencilerine teşekkür eder.

Ethics Committee Approval: The ethics committee approval was obtained from Kafkas University Faculty of Medicine Ethics Committee with the letter dated 13 December 2017 and numbered 181.

Conflict of Interest: There is no conflict of interest.

Funding: No financial support was received from any institution or person for this study.

Exhibitor Consent: All students participating in the study were informed about the research, and their consents were obtained.

\section{Author contributions}

Study design: FK, AKA

Data collection and analysis: FK, AKA

Literature search: FK, AKA

Drafting manuscript: FK, AKA

Acknowledgement: The authors would like to thank the Faculty of Health Sciences, Nursing Department students who participated in the study.

\section{KAYNAKLAR}

1. Boore J, Porter S. Education for entrepreneurship in nursing. Nurs Educ Today. 2011;(31):184-191.

2. İspir Ö, Elibol E, Sönmez B. The relationship of personality traits and entrepreneurship tendencies with career adaptability of nursing students. Nurs Educ Today. 2019;(79):41-47.
3. European Commission Directorate-General for Education and Culture. European Report On Qualıty Indicators of Lifelong Learnıng . Brussels: 2002;1-95.

4. Culha $Y$, Turan N, Kaya H. Entrepreneurshıp ın nursing education. PAP. 2017;4(1):50-53.

5. Wilson A, Whitaker N, Whitford D. Rising to the challenge of health care reform with entrepreneurial and Intrapreneurial nursing Initiatives. OJIN. 2012;17(2):5.

6. Shirey M.R et al. An evidence-based understanding of entrepreneurship in nursing, CNA. 2007;21(5):234-240.

7. Internatıonal Councll of nurses (ICN). Guidelines on The Nurse Entre/Intrapreneur Providing Nursing Service. Geneva, 2004.

8. Coşkun $Y$, Demirel $C$. Üniversite öğrencilerinin yaşam boyu öğrenme eğilimleri. H.U. Journal of Education. 2012;(42):108-120.

9. Akkoyunlu B, Kurbanoğlu S. Öğretmen adaylarının bilgi okuryazarlığı ve bilgisayar öz-yeterlik algıları üzerine bir çalışma. HÜEF Dergisi. 2003;(24):1-10.

10. Yilmaz $E$, Kaygin $H$. The relation between lifelong learning tendecy and achievement motivation. JETS. 2018;6(3a):1-7.

11. Aksoy M. Kavram olarak hayat boyu öğrenme ve hayat boyu öğrenmenin avrupa birliği serüveni. Bilig. 2013;(64):23-48.

12. Candy, P.C. Information literacy and lifelong learning. White Paper prepared for UNESCO, the U.S. National Commission on Libraries and Information Science, and the National Forum on Information Literacy, for use at the Information Literacy Meeting of Experts, Prague, The Czech Republic [internet]. 2002 [Erişim Tarihi 21 Aralık 2018]. Erişim adresi: http://www.nclis.gov/libinter/infolitconf\&meet/c andy-paper.html

13. Bath D.M, Smith C.D. The relationship between epistemological beliefs and the propensity for lifelong learning. Stud Cont Educ. 2009;31(2):173189.

14. Tezer M, Aynas N. The effect of university education on lifelong learning tendency. CJES. 2018;8(1):066-080.

15. Tamas A. The (not so) perfect match between the university graduates and the labor market. REJ. 2016;(59):183-216.

16. Karagözoğlu Ş. Hemşirelikte bireysel ve profesyonel özerklik. HEMAR-G. 2008;(10)3:197.

17. Hirst $S$. Lifelong learning, certıfication and registered nursing practice: their interrelatıonshıp. Papers on postsecondary learning and teaching: proceedings of the universiyt of calgary conference on learning and teaching. 2017;(2):10-15.

18. Akçakanat $\mathrm{T}$, Mücevher MH, Çarıkçı iH. Sözel, sayısal ve eşit ağırlık bölümlerinde okuyan üniversite öğrencilerinin girişimcilik eğilimlerinin 
bazı demografik değişkenler açısından incelenmesi: SDÜ Örneği. AKÜ Dergisi. 2014;(2):137-153.

19. Denat Y, Dikmen Y, Filiz NY, Başaran H. Hemşirelik öğrencilerinde yaşam boyu öğrenme eğilimleri. J. Hum. Rhythm. 2016;2(1):39-45.

20. Dolu iç, Temucin ED, Özkan HA. Hemşirelik öğrencilerinin girişimcilik düzeyleri ile bazı ilişkili faktörlerin değerlendirilmesi. JED/GKD. 2016;11(2);293-315.

21. Bahar A, Güler EK, Arslan $M$, İnem AB, Çimen ZS. Hemşirelik öğrencilerinde girişimcilik düzeyi ve etkileyen faktörlerin belirlenmesi. ACU Sağlık Bil Dergisi. 2019:10(3);529-534.

22. Yalçın IE, Uzun NB. Bireysel girişimcilik algı ölçeği: geçerlik ve güvenirlik çalışması. MKÜ Sosyal Bilimler Enstitüsü Dergisi. 2017;14(39):471-485.

23. Alpar R. Spor, sağlık ve eğitim bilimlerinden örneklerle uygulamalı istatistik ve geçerlikgüvenirlik. 2. Baskı. Ankara: Detay Yayınevi; 2012.

24. Kılıç Ç. Öğretmen adaylarının yaşam boyu öğrenmeye yönelik algıları. Jret. 2014;3(4):79-87.

25. Ilıman AY. Klasik Ve Entegre Eğitim Modeli İle Öğrenim Gören Hemşirelik Öğrencilerinde Problem Çözme Becerisi ve Yaşam Boyu Öğrenme Eğilimi [Yüksek Lisans Tezi]. İstanbul: Marmara Üniversitesi; 2017.

26. Karaduman A, Tarhan S. Üniversite öğrencilerinin yaşam boyu öğrenme eğilimleri ile özyeterlik algıları arasındaki ilişkinin belirlenmesi. JHS. 2017;14(14):355-375.

27. Pesen A, Epçaçan C. The analysis of high school students tendencies about lifelong learning. Hrpud. 2017;5(12A):26-31.

28. Çetin S, Çetin F. Lifelong learning tendencies of prospective teachers. JEP. 2017;8(12):1-8.

29. Dikmen Y, Yuvacı HU, Erol F. Tıp fakültesi öğrencilerinin yaşam boyu öğrenme eğilimlerinin incelenmesi. JHS. 2017;14(3):2399-2408.

30. Ekşioğlu S, Tarhan S, Gündüz HÇ. Yaşam boyu öğrenme eğilimleri ile özyetkinlik beklentisi ve kişilik özellikleri arasındaki ilişkinin incelenmesi. KEJ. 2017;25(5):1925-1940.

31. Arslan ŞF. Paramedik öğrencilerinde yaşam boyu öğrenme eğilimi. RESSJOURNAL. 2017;4(8):235243.

32. Tunca N, Şahin SA, Aydın Ö. Öğretmen adaylarının yaşam boyu öğrenme eğilimleri. MEÜEFD. 2015;11(2):432-446.

33. Arslan K. Üniversiteli gençlerde mesleki tercihler ve girişimcilik eğilimleri. Doğuş Üniversitesi Dergisi. 2002;(6):1-11.

34. Çelik A, İnce $M$, Bozyiğit $S$. Üniversiteli öğrencilerinin girişimcilik niyetlerini etkileyen ailesel faktörleri belirlemeye yönelik bir çalışma. Niğde Üniversitesi iïBF Dergisi. 2014;7(3):113-124.

35. Dashdamırova L. Duygusal Zekanın Girişimcilik Niyetine Etkisi: Üniversite Öğrencileri Üzerine Bir
Araştırma [Yüksek Lisans Tezi]. Samsun: Ondokuz Mayıs Üniversitesi; 2019.

36. Doğan E. The Effect of Entrepreneurshıp Education on Entrepreneurial Intentions of Universty Students In Turkey. EKOIST Ekonometri ve İstatistik Dergisi. 2015;(23):79-93.

37. Eminoğlu A. Hemşirelik öğrencilerinin Girişimcilik Özellikleri ve Eğilimleri [Yüksek Lisans Tezi]. Gaziantep: Gaziantep Üniversitesi; 2016.

38. Özbay L. Üniversite Öğrencilerinin Girişimcilik Eğilimlerinin Belirlenmesi: Dumlupınar Üniversitesinde Bir Araştırma [Yüksek Lisans Tezi]. Kütahya: Dumlupınar Üniversitesi; 2016.

39. Balkaya E. Üniversite Son Sınıf Öğrencilerinde İsssizlik Kaygısı ve Girişimcilik Niyeti İlişkisi: Tra 1 Bölgesi Örneği [Yüksek Lisans Tezi]. Erzurum: Atatürk Üniversitesi; 2017.

40. Karakulle I, Karakaya A. Üniversite öğrencilerinin girişimcilik eğilimleri üzerine bir araştırma. ASOS JOURNAL 2017;(46):596-614.

41. Türkmen $M$, İşbilir $U$. Üniversite öğrencilerinin girişimcilik eğilimlerinin sosyo-demografik özellikler açısından incelenmesi. CBU-BESBD. 2014;9(2):18-28.

42. Ekici E. Üniversite Öğrencilerinin Girişimcilik Eğilimini Belirlemede Planlanmış Davranışlar Teorisi ve Girişimcilik Eğitiminin Rolü [Yüksek Lisans Tezi]. Adana: Çukurova Üniversitesi; 2016.

43. Ayar U. Girişimcilik Eğitiminin Girişimcilik Eğilimi Üzerine Etkisi Ve Bir Araştırma [Yüksek Lisans Tezi]. İstanbul: İstanbul Üniversitesi; 2019.

44. Korkmaz O. Üniversite öğrencilerinin girişimcilik eğilimlerini belirlenmeye yönelik bir araştırma: Bülent Ecevit Üniversitesi Örneği. AKÜ- IïBF Dergisi. 2012;14(2):209-226.

45. Lee SM, Chang D, LIm SB. Impact of entrepreneurship educatıon: A comparative study of the U.S and Korea. IEMJ. 2005;(1):27-43.

46. Basu A, Virick M. Assessing entrepreneurial Intentions amongst students: A comparative study. NCIIA. 2008;(2):79-86.

47. Yanıkkrem E, Selçuk AK. Hemşirelik öğrencilerinin girişimcilik eğilimi ve sosyal medya bağımlıı̆̆ını etkileyen faktörler. CBU-SBED. 2019;6(1):15-30. 